\title{
Effect of Determined Mineral Elements in Mesocarp of Balanites Aegyptiaca Fruit on Serum Electrolytes of $\mathrm{Ccl}_{4}$ Treated Rats
}

\author{
${ }^{1}$ Salihu, M., ${ }^{2}$ Akpabio, C. J., ${ }^{3}$ Oloyede, O. B., ${ }^{3}$ Mohammed, N. O. \\ ${ }^{1}$ Biochemistry Unit, Biological sciences Department, Al-Hikmah University, Ilorin, Kwara State, Nigeria. \\ ${ }^{2}$ Department of Biochemistry, Basic Medical Sciences, University of Ibadan, Ibadan, Oyo State Nigeria. \\ ${ }^{3}$ Department of Biochemistry, University of Ilorin, Ilorin, Nigeria.
}

\begin{abstract}
This research assessed some of the mineral elements present in the mesocarp of the fruit of Balanites aegyptiaca and the effect of the fruits consumption on the serum electrolytes and kidney tissue enzymes of Carbon tetrachloride $\left(\mathrm{CCl}_{4}\right.$ ) treated rats. Sixty white albino rats (Rattus norvegicus) with average weight of 150 $\pm 11.45 \mathrm{~g}$ assigned to four (4) groups were used to assess the effect of the aqueous extract of the mesocarp of the fruit Balanites aegyptiaca on the rats. Group 1 were the normal control (Nc), group 2 were the diseased control (Dc) group, group 3 and 4 are the test groups of animals orally administered with $0.08 \mathrm{mgKg-}{ }^{1}$ of raw (Tr) extract and $0.19 \mathrm{mg} / \mathrm{kg}$ of concentrated (Tc) extracts daily. The methods used were cell fractionation,

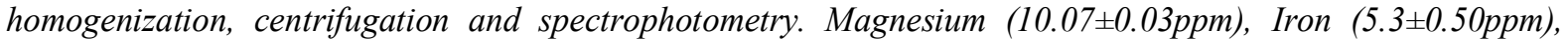
selenium (4.89 $\pm 1.26 \mathrm{ppm})$, copper $(2.47 \pm 0.19 \mathrm{ppm})$ and potassium $(1.77 \pm 0.06 \mathrm{ppm})$ were the major composition of determined minerals. The ash content was found to be $30.98 \pm 0.021 \%$ of the fruit mesocarp. The serum electrolytes showed that there was significant increase $(p<0.05)$ in the serum calcium, potassium, and sodium ions of tested rats compared to the control rats. Also there were elevations in the level of total proteins, albumin and conjugated bilirubin, the kidney tissue specific enzymes activities (alanine transaminase and alkaline phosphatase) indicated a significant reduction $(p<0.05)$ in levels on the test groups of rats compared to the diseased control. The result of this study shows some mineral elements in the fruit mesocarp of Balanites aegyptiaca, and their effects in the serum electrolytes and kidney tissue enzymes.
\end{abstract}

Keywords: Balanites aegyptiaca, Minerals, Carbon tetrachloride, kidney, Mesocarp, Enzymes.

\section{Introduction}

Balanites aegyptiaca (Balanitaceae) belongs to the family, Zygophyloceae, with the common names like desert date, soapberry, and thorn tree. ${ }^{1}$ The fruit fleshy outer parts (the mesocarp) were found to show hypoglycaemic activity on streptozotocin induced hyperglycaemia. ${ }^{2}$

An electrolyte is a substance containing free ions that behaves as an electrically conductive medium and the primary ions of electrolytes are sodium $\left(\mathrm{Na}^{+}\right)$, potassium $\left(\mathrm{K}^{+}\right)$, calcium $\left(\mathrm{Ca}^{2+}\right)$, magnesium $\left(\mathrm{Mg}^{2+}\right)$, chloride $\left(\mathrm{Cl}^{-}\right)$, phosphate $\left(\mathrm{PO}_{4}{ }^{3-}\right)$, and hydrogen carbonate $\left(\mathrm{HCO}_{3}^{-}\right){ }^{3}$ All higher life forms require a subtle and complex electrolyte balance between the intracellular and extracellular medium because the maintenance of precise osmotic gradients of electrolytes is important. ${ }^{4}$ Such gradients affect and regulate the body's hydration, blood $\mathrm{pH}$, and are critical for nerve and muscle functions. ${ }^{5}$ Muscles and neurons are activated by electrolyte activity between the extracellular fluid or interstitial fluid and intracellular fluid. Electrolyte balance is maintained by oral, or in emergencies, intravenous (IV) intake of electrolyte-containing substances, and is regulated by hormones, generally with the kidneys flushing out excess levels. In humans, electrolyte homeostasis is regulated by hormones such as antidiuretic hormone, aldosterone and parathyroid hormone. Serious electrolyte disturbances, such as dehydration and overhydration, may lead to cardiac and neurological complications and, unless they are rapidly resolved, will result in a medical emergency. ${ }^{3}$

Our bodies are bombarded daily with health hazards and irritants in the form of air pollution, synthetic drugs, chemicals in our water, and additives in the foods we eat. Many of these toxins are free radicals which can damage the membranes of our bodies' smallest units; our cells. Low levels of antioxidants, or inhibition of the antioxidant enzymes causes oxidative stress and may damage or kill cells. ${ }^{6}$ Furthermore, the cellular membrane is the site of all communication between the various systems of our body thus describes as the actual "brain" of the cell. Therefore, cellular membrane, more than any other part of our microscopic selves, controls who we are, discarding old notions of the nucleus as the most important feature. Moreover, radicals do not result only from pollution and synthetic toxins - they are a normal bi-product of digestion and cellular metabolism. ${ }^{7}$ No matter how healthy a diet and living space, the body still has to deal with free radicals and the damage they can do to the nervous system, eyesight, skin and organs, and overall vitality.

Minerals, Vitamin C and other vitamins are potent antioxidants. Some antioxidants such as lycopene and ascorbic acid can be destroyed by long-term storage or prolonged cooking. Antioxidants are found in varying amounts in foods such as vegetables, fruits, grain cereals, legumes and nuts but also culinary herbs and 
medicinal herbs can contain high levels of antioxidants. ${ }^{8}$ They are most effective, by far, in their natural form (from the fruits). In general, water-soluble antioxidants react with oxidants in the cell cytosol and the blood plasma, while lipid-soluble antioxidants protect cell membranes from lipid peroxidation. ${ }^{9}$ These compounds may be synthesized in the body or obtained from the diet.

The kidneys regulate the amount of water and salts that we have in our bodies. They do this by filtering the blood through millions of structures called nephrons. The kidneys also pass out certain waste products from the body. ${ }^{10}$ Urine is made up of the excess water, salts and waste products passed out by the kidneys down to the bladder which remove toxic waste products, remove excess water and salts, play a part in controlling your blood pressure, produce erythropoietin which stimulates red cell production from the bone marrow and also help to keep calcium and phosphate in balance for healthy bones, maintain the blood in a neutral (non-acid) state. ${ }^{9}$ Carbon tetrachloride does not dissolve in water very easily. High exposure to carbon tetrachloride can cause liver, and central nervous system damage. Kidneys also are damaged, causing a build up of wastes in the blood. However, if exposure is low and brief, the kidneys can repair the damaged cells and function normally again. ${ }^{11}$

This study determined the amount of some mineral elements in the fruit mesocarp and its effect in the serum electrolytes and kidney tissue enzymes.

\section{Materials and Methods}

The ash of a biological material is an analytical term for the inorganic residue that remains after the organic matter has been burnt away. ${ }^{12}$ The method used was as described by Pearson. ${ }^{13}$ Mineral determination was done by using Perchloric acid digestion modified by Perkin-Elmer Corp. ${ }^{14}$

\section{Determination of Serum Calcium, Sodium and Potassium}

Tietz colorimetric method was used for the calcium determination. The absorbance was measured at $580 \mathrm{~nm}$ which is proportional to the amount of calcium ion in the serum. Flame photometry method was used as described by Tietz for sodium and potassium. ${ }^{15}$

\section{Determination of Serum Phosphate}

This was done by colorimetric method as described by Taussky et al. Measured at $690 \mathrm{~nm} .{ }^{16}$

\section{Determination of Creatinine in the Serum}

Creatinine concentration was determined as described by Blass. ${ }^{17}$

\section{Determination of Serum Urea}

The method used for the determination of urea in the serum was by diacetyl monoxime using thiosemicarbazide as described by Veniamin and Vakirtzi. ${ }^{18}$

\section{Alkaline Phosphatase Activity Determination}

The method used for the determination of alkaline phosphatase activity was that described by Bassey et al. ${ }^{19}$ and modified by Wright et al., in which the enzyme hydrolyzed para-nitrophenyl phosphate to give paranitrophenol and phosphoric acid with $\mathrm{Mg}^{2+}$ serving as an activator. ${ }^{20}$

\section{Alanine Transaminase Activity Determination}

Alanine transaminase was measured by monitoring the concentration of pyruvate formed from 2,4dinitrophenyl hydrazine as described by Reitman and Frankel. ${ }^{21}$

\section{Animals Grouping}

Group 1 - The normal control rats (Nc).

Group 2 - The test control rats (Dc).

Group 3 - The treated with mesocarp extract of $0.08 \mathrm{mg} / \mathrm{kg}$ body weight of the rats $(\mathrm{Tr})$.

Group 4 - The treated with mesocarp extract of $0.19 \mathrm{mg} / \mathrm{kg}$ body weight rats $(\mathrm{Tc})$. 


\section{Results and Discussions}

Table 1: Mineral Elements in the Mesocarp of Balanites aegyptiaca Fruit.

\begin{tabular}{lll}
\hline Elements & Concentration $(\mathbf{p p m})$ & Percentage $(\%)$ minerals determined \\
\hline Phosphorus & $1.32 \pm 0.02$ & 4.87 \\
Sodium & $0.05 \pm 0.01$ & 0.18 \\
Cobalt & $0.01 \pm 0.00$ & 0.04 \\
Magnesium & $10.07 \pm 0.30$ & 37.13 \\
Copper & $2.47 \pm 0.19$ & 9.12 \\
Selenium & $4.89 \pm 1.26$ & 18.03 \\
Calcium & $0.75 \pm 0.01$ & 2.77 \\
Manganese & $0.37 \pm 0.02$ & 0.14 \\
Zinc & $0.06 \pm 0.00$ & 0.22 \\
Iron & $5.30 \pm 0.50$ & 19.54 \\
Potassium & $1.77 \pm 0.06$ & 6.53 \\
\hline
\end{tabular}

Each value is mean $\pm \operatorname{SEM}(n=5)$

Table 2: Serum Electrolytes Parameters of the Rats Treated with Aqueous Extract of the Mesocarp of Balanites aegyptiaca.

\begin{tabular}{|c|c|c|c|c|c|c|}
\hline Parameter & $\begin{array}{l}\text { Animals } \\
\text { Grouping }\end{array}$ & $2^{\text {nd }}$ day & $4^{\text {th }}$ day & $8^{\text {th }}$ day & $14^{\text {th }}$ day & $21^{\text {st }}$ day \\
\hline \multirow{4}{*}{$\begin{array}{ll}\text { Sodium } & \text { ion } \\
(\mathrm{mmol} / \mathrm{l}) & \end{array}$} & Group 1 & $136.5 \pm 12.06^{b}$ & $142.3 \pm 14.80^{b}$ & $125.3 \pm 12.00^{\mathrm{a}}$ & $130.0 \pm 14.08^{b}$ & $132.0 \pm 10.08^{b}$ \\
\hline & Group 2 & $135.7 \pm 11.08^{\mathrm{a}}$ & $136.0 \pm 12.05^{\mathrm{a}}$ & $129.3 \pm 9.08^{b}$ & $126.4 \pm 11.08^{\mathrm{a}}$ & $127.1 \pm 16.80^{a}$ \\
\hline & Group 3 & $138.0 \pm 10.06^{\mathrm{c}}$ & $136.0 \pm 11.82^{a}$ & $140.7 \pm 11.12^{\mathrm{d}}$ & $142.0 \pm 12.60^{\mathrm{c}}$ & $138.0 \pm 10.03^{c}$ \\
\hline & Group 4 & $136.7 \pm 12.08^{b}$ & $141.7 \pm 10.72^{b}$ & $134.7 \pm 11.12^{\mathrm{c}}$ & $132.0 \pm 10.50^{\mathrm{b}}$ & $137.0 \pm 11.02^{\mathrm{c}}$ \\
\hline \multirow{4}{*}{$\begin{array}{l}\text { Potassium } \\
\text { ion }(\mathrm{mmol} / \mathrm{l})\end{array}$} & Group 1 & $4.2 \pm 0.02^{b}$ & $6.5 \pm 0.41^{\mathrm{a}}$ & $8.5 \pm 0.07^{\mathrm{b}}$ & $7.2 \pm 0.31^{\mathrm{a}}$ & $8.0 \pm 0.07^{\mathrm{a}}$ \\
\hline & Group 2 & $4.7 \pm 0.14^{\mathrm{c}}$ & $8.0 \pm 0.22^{\mathrm{c}}$ & $12.5 \pm 0.15^{\mathrm{d}}$ & $16.3 \pm 0.23^{c}$ & $19.4 \pm 0.21^{\mathrm{c}}$ \\
\hline & Group 3 & $4.0 \pm 0.23^{\mathrm{a}}$ & $7.1 \pm 0.34^{b}$ & $5.5 \pm 0.19^{\mathrm{a}}$ & $6.5 \pm 0.10^{\mathrm{b}}$ & $8.1 \pm 0.32^{\mathrm{a}}$ \\
\hline & Group 4 & $4.2 \pm 0.08^{b}$ & $7.4 \pm 0.08^{b}$ & $10.7 \pm 0.20^{\mathrm{c}}$ & $11.5 \pm 0.21^{\mathrm{c}}$ & $17.5 \pm 0.41^{b}$ \\
\hline \multirow{4}{*}{$\begin{array}{l}\mathrm{HCO}_{3}^{-} \\
(\mathrm{mmol} / \mathrm{l})\end{array}$} & Group 1 & $18.0 \pm 1.21^{\mathrm{a}}$ & $21.3 \pm 1.53^{c}$ & $18.3 \pm 1.72^{b}$ & $22.1 \pm 0.86^{\mathrm{c}}$ & $21.8 \pm 1.21^{\mathrm{c}}$ \\
\hline & Group 2 & $19.7 \pm 0.91^{b}$ & $19.0 \pm 0.82^{\mathrm{a}}$ & $16.3 \pm 1.53^{a}$ & $13.4 \pm 0.92^{\mathrm{a}}$ & $12.9 \pm 1.01^{\mathrm{a}}$ \\
\hline & Group 3 & $20.7 \pm 2.91^{b}$ & $20.0 \pm 1.71^{b}$ & $19.7 \pm 1.21^{\mathrm{c}}$ & $20.2 \pm 0.17^{\mathrm{b}}$ & $21.3 \pm 2.03^{c}$ \\
\hline & Group 4 & $21.7 \pm 3.11^{\mathrm{c}}$ & $20.0 \pm 2.01^{b}$ & $18.3 \pm 2.01^{\mathrm{b}}$ & $19.6 \pm 1.03^{b}$ & $19.9 \pm 0.82^{b}$ \\
\hline \multirow{4}{*}{$\begin{array}{l}\text { Chloride ion } \\
(\mathrm{mmol} / \mathrm{l})\end{array}$} & Group 1 & $100 \pm 5.01^{\mathrm{a}}$ & $97.3 \pm 8.08^{b}$ & $80.0 \pm 1024^{b}$ & $79.1 \pm 5.00^{c}$ & $82.1 \pm 10.21^{\mathrm{c}}$ \\
\hline & Group 2 & $101 \pm 3.51^{\mathrm{a}}$ & $86.5 \pm 7.31^{\mathrm{a}}$ & $69.3 \pm 5.21^{\mathrm{a}}$ & $66.5 \pm 4.08^{a}$ & $62.3 \pm 9.10^{\mathrm{a}}$ \\
\hline & Group 3 & $299 \pm 9.21^{\mathrm{b}}$ & $172 \pm 10.21^{\mathrm{c}}$ & $99.3 \pm 3.11^{\mathrm{d}}$ & $94.8 \pm 5.44^{d}$ & $88.6 \pm 8.20^{d}$ \\
\hline & Group 4 & $100.3 \pm 2.90^{\mathrm{a}}$ & $98 \pm 4.99^{b}$ & $77.7 \pm 11.92^{b}$ & $72.6 \pm 14.07^{b}$ & $68.9 \pm 11.33^{b}$ \\
\hline \multirow{4}{*}{$\begin{array}{l}\text { Calcium ion } \\
(\mathrm{mmol} / \mathrm{l})\end{array}$} & Group 1 & $2.27 \pm 0.07^{\mathrm{c}}$ & $2.25 \pm 0.07^{\mathrm{a}}$ & $2.25 \pm 0.87^{b}$ & $2.24 \pm 02^{\mathrm{a}}$ & $2.27 \pm 0.02^{\mathrm{b}}$ \\
\hline & Group 2 & $2.21 \pm 0.04^{\mathrm{a}}$ & $2.19 \pm 0.02^{\mathrm{a}}$ & $2.12 \pm 0.21^{\mathrm{a}}$ & $2.02 \pm 0.01^{\mathrm{a}}$ & $1.94 \pm 0.01^{\mathrm{a}}$ \\
\hline & Group 3 & $2.42 \pm 1.08^{\mathrm{a}}$ & $2.56 \pm 0.01^{b}$ & $2.61 \pm 0.03^{b}$ & $2.62 \pm 0.71^{b}$ & $2.71 \pm 0.03^{\mathrm{C}}$ \\
\hline & Group 4 & $2.28 \pm 0.02^{\mathrm{c}}$ & $3.10 \pm 0.01^{b}$ & $3.43 \pm 0.02$ & $3.01 \pm 0.42^{\mathrm{C}}$ & $3.21 \pm 0.02^{\mathrm{C}}$ \\
\hline \multirow{4}{*}{$\begin{array}{l}\text { Phosphate } \\
(\mathrm{mmol} / \mathrm{l})\end{array}$} & Group 1 & $1.08 \pm 0.02^{\mathrm{a}}$ & $1.08 \pm 0.02^{b}$ & $1.09 \pm 0.33^{\mathrm{a}}$ & $1.10 \pm 0.03^{\mathrm{a}}$ & $1.09 \pm 0.22^{\mathrm{a}}$ \\
\hline & Group 2 & $0.85 \pm 0.04^{\mathrm{a}}$ & $0.97 \pm 0.01^{\mathrm{a}}$ & $1.22 \pm 0.91^{\mathrm{c}}$ & $1.61 \pm 0.10^{b}$ & $1.74 \pm 0.17^{\mathrm{c}}$ \\
\hline & Group 3 & $0.95 \pm 0.06^{b}$ & $1.12 \pm 0.04^{\mathrm{c}}$ & $1.12 \pm 0.04^{b}$ & $1.10 \pm 0.64^{\mathrm{a}}$ & $1.09 \pm 0.29^{\mathrm{a}}$ \\
\hline & Group 4 & $1.10 \pm 0.03^{b}$ & $1.13 \pm 0.07^{\mathrm{c}}$ & $1.14 \pm 0.21^{b}$ & $1.09 \pm 0.36^{\mathrm{a}}$ & $1.15 \pm 0.30^{\mathrm{b}}$ \\
\hline
\end{tabular}

Each value is mean $\pm \operatorname{SEM}(n=4$ in a group)

Values along the same column with different superscripts are significantly different $(\mathbf{p}<0.05)$

As could be observed from result on Table 2, the serum level of potassium ions in the rats was significantly low $(\mathrm{p}<0.05)$ compared with sodium ion and this was significant increased $(\mathrm{p}<0.05)$ in the Dc and Tc (i.e. groups 2 and 4 ) animals as from the $4^{\text {th }}$ day of the administration. However, it had been reported that potassium is normally released during cells breakdown and is used in building nucleic acids of the cells. ${ }^{22}$ Thus some people with kidney disease are advised to avoid large quantities of dietary potassium, since the kidneys control potassium excretion, and buildup of blood concentrations of potassium may trigger fatal cardiac arrhythmia $^{23}$ Furthermore, bicarbonate ion in the serum of the rats was observed to be almost reverse of what was obtained in the sodium ion level as there was significant gradual reduction $(p<0.05)$ in the level of bicarbonate ion in the Dc animals throughout the experiment. Bicarbonate is a chemical found in the blood and is a crucial component of the acid/base system of the body for maintaining homeostasis. ${ }^{23}$ The effects of the administration on the chloride ion by the rats was not significantly different except in the Tr animal which was significantly increased $(p<0.05)$ from $2^{\text {nd }}$ day but reduced to almost non-significant level compared to the other groups toward the rest of the experiment. The effects on the calcium ion of the experimental animals (Table 2) showed that there was significant increase $(\mathrm{p}<0.05)$ in the treated animal calcium level compared to the untreated groups. Calcium has also been found to assist in the production of lymphatic fluids and many biological processes like muscle contraction, intracellular second messenger for hormones and in transfer of nerve impulses and in blood clotting. ${ }^{24}$ The non-significant effect $(p<0.05)$ on the serum phosphate ion concentration shown by the animals except the diseased untreated control (Dc) may be as a result of phosphate 
ions not accumulated enough to produce significant change. ${ }^{25}$ The initial reduction observed in the diseased control could indicate tubular dysfunction of the nephrons..$^{26}$

Table 3: Serum Liver Function Indices of the $\mathbf{C C l}_{4}$-Induced Rats Treated with Aqueous Extract of the

\begin{tabular}{lllllll}
\multicolumn{7}{c}{ Mesocarp of Balanites aegyptiaca } \\
\hline Parameter & $\begin{array}{l}\text { Animals } \\
\text { Grouping }\end{array}$ & $2^{\text {nd }}$ day & $\mathbf{4}^{\text {th }}$ day & $\mathbf{8}^{\text {th }}$ day & $\mathbf{1 4}^{\text {th }}$ day & $\mathbf{2 1}^{\text {st }}$ day \\
\hline Urea & Group 1 & $7.1 \pm 0.92^{\mathrm{c}}$ & $7.7 \pm 0.52^{\mathrm{c}}$ & $8.2 \pm 1.09^{\mathrm{c}}$ & $7.9 \pm 1.08^{\mathrm{b}}$ & $7.7 \pm 0.13^{\mathrm{b}}$ \\
$(\mathrm{mmol} / \mathrm{l})$ & Group 2 & $6.6 \pm 0.66^{\mathrm{a}}$ & $6.2 \pm 1.22^{\mathrm{a}}$ & $5.3 \pm 0.63^{\mathrm{a}}$ & $5.1 \pm 0.09^{\mathrm{a}}$ & $5.3 \pm 0.02^{\mathrm{a}}$ \\
& Group 3 & $6.9 \pm 1.02^{\mathrm{b}}$ & $7.1 \pm 2.08^{\mathrm{b}}$ & $7.2 \pm 0.51^{\mathrm{b}}$ & $7.7 \pm 0.18^{\mathrm{b}}$ & $8.1 \pm 0.16^{\mathrm{c}}$ \\
& Group 4 & $7.1 \pm 0.97^{\mathrm{c}}$ & $7.3 \pm 0.92^{\mathrm{b}}$ & $8.0 \pm 2.10^{\mathrm{c}}$ & $8.3 \pm 0.13^{\mathrm{c}}$ & $9.2 \pm 2.15^{\mathrm{c}}$ \\
Urate & Group 1 & $6.4 \pm 0.24^{\mathrm{a}}$ & $6.3 \pm 0.21^{\mathrm{a}}$ & $6.1 \pm 0.27^{\mathrm{a}}$ & $6.3 \pm 0.31^{\mathrm{a}}$ & $6.3 \pm 0.27^{\mathrm{a}}$ \\
$(\mathrm{mmol} / \mathrm{l})$ & Group 2 & $6.1 \pm 0.61^{\mathrm{a}}$ & $6.0 \pm 0.36^{\mathrm{a}}$ & $5.9 \pm 0.28^{\mathrm{a}}$ & $5.8 \pm 0.42^{\mathrm{a}}$ & $6.0 \pm 0.29^{\mathrm{a}}$ \\
& Group 3 & $6.8 \pm 1.00^{\mathrm{b}}$ & $7.1 \pm 0.21^{\mathrm{b}}$ & $7.4 \pm 0.14^{\mathrm{b}}$ & $7.5 \pm 0.22^{\mathrm{b}}$ & $7.7 \pm 0.41^{\mathrm{b}}$ \\
& Group 4 & $7.4 \pm 0.57^{\mathrm{c}}$ & $7.7 \pm 0.35^{\mathrm{c}}$ & $7.9 \pm 0.23^{\mathrm{c}}$ & $9.8 \pm 0.81^{\mathrm{c}}$ & $9.9 \pm 0.63^{\mathrm{c}}$ \\
Creatinine & Group 1 & $42.3 \pm 5.17^{\mathrm{c}}$ & $46.3 \pm 3.79^{\mathrm{b}}$ & $42.7 \pm 6.12^{\mathrm{b}}$ & $44.5 \pm 1.25^{\mathrm{d}}$ & $43.6 \pm 3.46^{\mathrm{c}}$ \\
$(\mu \mathrm{mol} / \mathrm{l})$ & Group 2 & $44.0 \pm 2.00^{\mathrm{d}}$ & $53.0 \pm 6.08^{\mathrm{c}}$ & $46.7 \pm 3.26^{\mathrm{c}}$ & $32.8 \pm 2.57^{\mathrm{a}}$ & $31.9 \pm 4.83^{\mathrm{a}}$ \\
& Group 3 & $38.0 \pm 2.00^{\mathrm{a}}$ & $37.0 \pm 1.68^{\mathrm{a}}$ & $38.3 \pm 8.14^{\mathrm{a}}$ & $38.9 \pm 5.61^{\mathrm{b}}$ & $38.0 \pm 6.21^{\mathrm{b}}$ \\
& Group 4 & $40.0 \pm 3.21^{\mathrm{b}}$ & $39.0 \pm 4.53^{\mathrm{a}}$ & $40.4 \pm 7.22^{\mathrm{b}}$ & $41.8 \pm 4.22^{\mathrm{c}}$ & $40.6 \pm 3.02^{\mathrm{b}}$ \\
\hline
\end{tabular}

Each value is mean \pm SEM $(n=4$ in a group)

Values along the same column with different superscripts are significantly different $(\mathbf{p}<0.05)$

Table 3 shows the effects of the administration of aqueous extract of Balanites aegyptiaca fruit mesocarp on the urea level of the experimental rats. As could be observed, there was gradual significant reduction $(p<0.05)$ in the urea level of the rats from day 2 till the $21^{\text {st }}$ day of the experiment. While the levels for controls and the Tr rats were relatively not significantly different $(p<0.05)$ but increased $(p<0.05)$ gradually with the days of experiment. However, the urate level of Dc rats was lowest among the groups while the treated rats gradually increased as the creatinine level reduces.

Table 4: Activities of Enzymes in Kidney of $\mathbf{C C l}_{4}$-Induced Rats Treated with Aqueous Extract of Mesocarp of Balanites aegyptiaca

\begin{tabular}{|c|c|c|c|c|c|c|}
\hline Parameter & $\begin{array}{l}\text { Animals } \\
\text { Grouping }\end{array}$ & $2^{\text {nd }}$ day & $4^{\text {th }}$ day & $8^{\text {th }}$ day & $14^{\text {th }}$ day & $21^{\text {st }}$ day \\
\hline Alkaline & Group 1 & $25.62 \pm 1.12^{\mathrm{a}}$ & $25.72 \pm 1.07^{\mathrm{a}}$ & $25.62 \pm 1.21^{\mathrm{a}}$ & $26.13 \pm 0.01^{\mathrm{a}}$ & $25.93 \pm 0.92^{\mathrm{a}}$ \\
\hline \multirow[t]{3}{*}{ phosphatase } & Group 2 & $42.15 \pm 1.09^{c}$ & $44.21 \pm 5.24^{\mathrm{c}}$ & $44.99 \pm 4.11^{\mathrm{c}}$ & $47.23 \pm 4.01^{\mathrm{d}}$ & $47.80 \pm 4.67^{d}$ \\
\hline & Group 3 & $40.01 \pm 1.11^{\mathrm{b}}$ & $38.60 \pm 1.39^{b}$ & $35.16 \pm 0.34^{b}$ & $33.68 \pm 1.54^{b}$ & $33.01 \pm 5.81^{b}$ \\
\hline & Group 4 & $41.10 \pm 0.70^{\mathrm{a}}$ & $41.39 \pm 4.19^{a}$ & $42.09 \pm 1.32^{b}$ & $41.95 \pm 3.35^{\mathrm{b}}$ & $42.31 \pm 2.10^{\mathrm{b}}$ \\
\hline Alanine & Group 1 & $30.36 \pm 2.41^{\mathrm{a}}$ & $30.61 \pm 0.19^{a}$ & $30.50 \pm 0.12^{\mathrm{a}}$ & $30.53 \pm 0.61^{\mathrm{a}}$ & $30.49 \pm 1.56^{\mathrm{a}}$ \\
\hline \multirow{3}{*}{ transaminase } & Group 2 & $44.20 \pm 2.08^{c}$ & $43.36 \pm 0.91^{\mathrm{c}}$ & $43.64 \pm 3.57^{\mathrm{c}}$ & $43.72 \pm 0.22^{\mathrm{d}}$ & $43.87 \pm 1.11^{\mathrm{d}}$ \\
\hline & Group 3 & $41.01 \pm 0.01^{\mathrm{b}}$ & $40.13 \pm 0.10^{\mathrm{b}}$ & $42.01 \pm 1.12^{b}$ & $42.47 \pm 3.20^{\mathrm{b}}$ & $42.93 \pm 1.10^{\mathrm{b}}$ \\
\hline & Group 4 & $40.12 \pm 0.01^{\mathrm{b}}$ & $39.17 \pm 0.32^{b}$ & $39.66 \pm .09^{\mathrm{b}}$ & $39.89 \pm 2.8^{c}$ & $40.65 \pm 0.06^{\mathrm{c}}$ \\
\hline
\end{tabular}

Each value is a mean \pm SEM $(n=4$ in a group)

Values along the same column with different superscripts are significantly different $(\mathbf{p}<0.05)$

The enzymes activities in the kidney of the $\mathrm{CCl}_{4}$-treated rats (Table 5) was elevated $(\mathrm{P}<0.05)$ for both the alanine transaminase and alkaline phosphatase. But the levels for the normal control rats $(\mathrm{Nc})$ were maintained at relative level throughout the experiment. However, the enzymes activities for the Tr rats gradually reduced while that of Tc rats increased steadily as the days increased.

The result of this study seems to justify that mineral supplement should never be used as substitute to a good diet rich in fruits. The importance of diet in the management of diseases can not be over emphasized because it is cheap, easy to get and has minimum negative side effects unlike that of chemotherapeutic agents or drugs which makes the researchers to be of opinion that dietary therapy should not suffered neglects as a result of the production of synthetic drugs.

\section{Reference}

[1]. Gills, L. S. The Ethnomedical Used plants in Nigeria, (Uniben Press, Benin, Nigeria. 1992), p.276.

[2]. Creach, P. Balanites aegyptiaca and its various uses in Tchad territory Rev. Institute of Botanical application in Tropical agric.(1943) 20: $578-582$

[3]. Coso J,Estevez E,Baquero E,Mora-Rodriguez R. "Anaerobic performance when rehydrating with water or commercially available sports drinks during prolonged exercise in the heat". Applied Physiology, Nutrition and Metabolism, 2008,33 (2): $290-298$.

[4]. Bell, A. Mineral content of yam tubers: Raw, boiled and as flour. In 'Tropical Root Crops: production and uses in Africa"( IDRC221e, Ottawa, 1984)157-160.

[5]. Banks, P., Bartley, W. and But, L. M. The Biochemistry of the tissues (2 ${ }^{\text {nd }}$ Ed.), 1978, John Wiley and Sons, Chichester, New York.

[6]. Roberts, M. B. V. The principle of homeostasis, Biology, a functional approach, $2^{\text {nd }}$ ed., (Thomas Nelson and Sons Ltd, Edinburg. 1976) $207-208$. 
[7]. Mitchell, Rynbergen, Anderson and Dibble. Nutrition in health and diseases.( $16^{\text {th }}$ Edition, 1976) $70-111$.

[8]. Dragland S Senoo H, Wake K, Holte K, Blomhoff R. "Several Culinary and Medicinal Herbs are Important Sources of Dietary Antioxidants", J Nutr. 2003 May; 133(5):1286-90

[9]. Bjelakovic G. "Mortality in randomized trials of antioxidant supplements for primary and secondary prevention: systematic review and meta-analysis". JAMA, 2007, 297 (8): 842-57.

[10]. Chawla, R. Kidney function tests. In: Practical Clinical Biochemistry Methods and Interpretation. ( $2^{\text {nd }}$ edition) ( JAYPEE Brothers Medical Publishers Ltd 1999, 90-92) New Delhi, India.

[11]. Sharhjahan, M., Sabitha, K. E., Mallika, J. and Shyamala-Devi, C. S. Effect of Solanum trilobatum against carbon tetrachloride induced hepatic damage in Albino rats. Indian J. Med. Res., 2004, 120: 194-198.

[12]. Oyeleke, O. A. Outlines of Food Analysis, 1984. Department of Biochemistry, University Of Ilorin, Nigeria.

[13]. Pearson, P. The Chemical Analysis of Foods ( $9^{\text {th }}$ Edition) J.A Churchill, London Production 1981,479 .

[14]. Perkin-Elmer Corporation Anal. Chem., 1968, 40 (8), pp 66A-66A. America Chemical Society.

[15]. Tietz, N. W. Clinical guide to laboratory tests. $3^{\text {rd }}$ edition.1995, 518-519. W. B. Sauders company. Philadelphia.

[16]. Taussky, H.H., Shorr, E., and Kurzmann, G. A microcolorimeteric methods for determination of inorganic phosphorus. J. Biol. Chem., 1953, 202: 675-685.

[17]. Blass, K. G., Thiebert, R. J. and Lam, L. K. Study of mechanism of JAFE reactions. Clin. Chem.1974, 12(7): 336-343.

[18]. Veniamin, M.P. and Varkirtzi, C. Chemical basis of the carbamidodi-acetyl micro-method for estimation of urea, cirulline and carbamyl derivatives. Clinical Chemistry.1970, 16: 3-6.

[19]. Bassey, O. A., Lowry, O. H and Brock, M. D. (1946): A method for rapid determination of Alkaline Phosphatase with cubic millimeter of serum. J. Biol. Chem. 164: $321-392$.

[20]. Wright, P. J., Leatwood, P.O. and Plummer, D. T. Enzymes in rats urine, Alkaline Phosphatase. Enzymologia. 1972, 42: 459 - 460.

[21]. Reitman,S. And Frankel S. A colorimetric method for the determination of serum oxaloacetic and glutamic pyruvic transmnases. Am. J. Clin. Pathol 1957, 28: 56-63.

[22]. Philip, D. M. Plasma enzymes in diagnosis. In: Clinical chemistry in diagnosis and treatment. $6^{\text {th }}$ edition. 1995, 303-30.Oxford University Press, Inc., New York.

[23]. Goldberg, Robert N. Kishore, Nand; Lennen, Rebecca M. "Thermodynamic quantities for the ionization reactions of buffers in water". CRC Handbook. 2003, 7-13.

[24]. Guyton, A. C. and Hall, J. E. Textbook of Medical Physiology. $10^{\text {th }}$ edition, 2000, 782-783. Harcourt International edition. W.B. Sanders Company, Philadelphia, USA.

[25]. Adebayo, J. O., Egwin, E. C., Enaibe, B. U., Owoyele, V. B. and Yakubu, M. T. Effect of ethanoic extract of Khaya senegalensis on some biochemical parameters of rat kidney. J. Ethnopharm. 2003, 88: 69-72. 